\title{
High concentration of MSG alters antioxidant defence system in lobster cockroach Nauphoeta cinerea (Blattodea: Blaberidae)
}

\author{
Blessing A. Afolabi ${ }^{1,2,3^{*}}$ (D) and Olawande C. Olagoke ${ }^{2}$
}

\begin{abstract}
Objective: Monosodium glutamate (MSG) is a food additive that has been shown to be toxic to rodents at high concentrations. The available studies in Drosophila melanogaster suggest that MSG toxicity depends on concentration and gender, thus the safety of MSG as a food enhancer still requires further investigation. We have documented impaired locomotor activity and altered oxidative stress markers in cockroaches co-exposed to methylmercury and monosodium glutamate (MSG). We herein examined the susceptibility of Nauphoeta cinerea to high and low concentrations ( $4 \%$ and $1 \%$ ) of MSG, while monitoring the activities of acetylcholinesterase (AChE), as well as markers of oxidative stress and antioxidant activity over 30 days.

Results: There was no significant alteration in the parameters assessed at 1\% MSG while 4\% MSG caused an increase in the activity of reactive oxygen and nitrogen species, with a corresponding reduction in the activities of acetylcholinesterase, glutathione-S-transferase and catalase, suggesting the capacity of MSG to alter redox homeostasis in Nauphoeta cinerea.
\end{abstract}

Keywords: Nauphoeta cinerea, Monosodium glutamate, Catalase, Glutathione-S-Transferase, Total thiol, Acetylcholinesterase, Oxidative stress, Food additive

\section{Introduction}

Monosodium glutamate [(MSG), (e-number E621)], is known to be one of the most widely used food enhancer [1], apart from the common table salt. MSG is a derivative of glutamate and an abundant non-essential amino acid in nature. The average daily intake of MSG in humans is estimated to be $300-1000 \mathrm{mg}$, although this varies in different countries [2]. Organizations and nutritionists endorse it and also reiterate its safety in humans [3], however, debates persist over the health implications of MSG consumption. Several animal studies have linked MSG with oxidative stress and toxicity to the liver,

\footnotetext{
*Correspondence: blessingafolabi7@gmail.com

${ }^{1}$ Departamento de Bioquímica, Instituto de Ciências Básicas da Saúde, Universidade Federal do Rio Grande do Sul, Rua Ramiro Barcelos 2600-Anexo, 90035-003 Porto Alegre, RS, Brazil

Full list of author information is available at the end of the article
}

kidney or reproductive organs [4-7]. Recently, studies have shown an adaptive response to oxidative stress in Drosophila melanogaster and a reduction in life span after short exposure to MSG diet [8]. However, another study in D. melanogaster showed that MSG could be safe at extremely low concentrations, though high concentration caused alterations in catalase activity [9].

The cockroach is a promising model being utilized for toxicological and behavioural experiments [10-13]. The biophysical principles of nervous system function in insects and mammals are analogous because they possess similar neurotransmitters, albeit their distributions vary widely $[14,15]$. Thus, as an alternative to conventional animal models, the present study investigated the effect of MSG compounded diet on acetylcholinesterase, as well as markers of oxidative stress and antioxidant activity in N. cinerea.

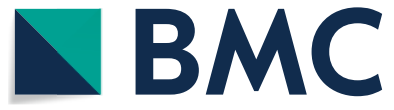

(c) The Author(s) 2020. This article is licensed under a Creative Commons Attribution 4.0 International License, which permits use, sharing, adaptation, distribution and reproduction in any medium or format, as long as you give appropriate credit to the original author(s) and the source, provide a link to the Creative Commons licence, and indicate if changes were made. The images or other third party material in this article are included in the article's Creative Commons licence, unless indicated otherwise in a credit line to the material. If material is not included in the article's Creative Commons licence and your intended use is not permitted by statutory regulation or exceeds the permitted use, you will need to obtain permission directly from the copyright holder. To view a copy of this licence, visit http://creativeco mmons.org/licenses/by/4.0/. The Creative Commons Public Domain Dedication waiver (http://creativecommons.org/publicdomain/ zero/1.0/) applies to the data made available in this article, unless otherwise stated in a credit line to the data. 


\section{Main text}

\section{Materials and methods} Chemicals

Monosodium glutamate (MSG 99\% purity Ajinomoto ${ }^{\circledR}$ ) was gotten from Carrefour supermarket in Santa MariaRS, Brazil. Sigma Aldrich (St. Louis, MO, USA) supplied sodium chloride, glutathione, 1-chloro-2,4 dinitrobenzene (CDNB), 5',5'-dithiobis-2-nitrobenzoic acid (DTNB), acetylthiocholine iodide, and hydrogen peroxide $\left(\mathrm{H}_{2} \mathrm{O}_{2}\right)$. All other chemicals were of high purity while the water was glass distilled.

\section{Cockroach husbandry and experimental protocol}

Nauphoeta cinerea was obtained from Departamento de Bioquímica e Biologia Molecular, CCNE, Universidade Federal de Santa Maria, Brasil. Plastic boxes $(45.5 \mathrm{~cm} \times 40.2 \mathrm{~cm} \times 29.5 \mathrm{~cm})$ were used to rear the nymphs before some were randomly selected into transparent boxes $(25 \mathrm{~cm} \times 17 \mathrm{~cm} \times 7.5 \mathrm{~cm})$ for the experiment. They were acclimatized in the transparent box for 10 days before exposure to MSG diet and maintained at a temperature and humidity of $\pm 26{ }^{\circ} \mathrm{C}$ and $\pm 75 \%$ respectively. Nymphs of $N$. cinerea were selected for this study because it is the most active developmental stage and their age can be estimated from the length. In addition, the adults rarely increase in length. The nymphs used for both studies had lengths ranging from 1.09 to $1.76 \mathrm{~cm}$ at the start and 1.12 to $1.86 \mathrm{~cm}$ at the end of the experiment.

The insects could freely access water and standard dog food as composed in Afolabi et al. [10] during rearing and adaptation. For the diet, MSG (1\% or $4 \%)$ or $\mathrm{NaCl}(1 \%$ or $4 \%$ ) was mixed with a $20 \mathrm{~g}$ diet containing $10 \mathrm{~g}$ milled corn flour, $7 \mathrm{~g}$ wheat flour, $2 \mathrm{~g}$ granulated sugar, $0.5 \mathrm{~g}$ casein, $0.4 \mathrm{~g}$ powder milk and $0.1 \mathrm{~g}$ table salt and stored at $-20{ }^{\circ} \mathrm{C}$. Both studies consisted of 3 groups of 30 nymphs each, nymphs from the first study were exposed to basal diet (control), 4\% $\mathrm{NaCl}$ and 4\% MSG, while nymphs for the second study were exposed to basal diet (control), 1\% $\mathrm{NaCl}$ and 1\% MSG for 30 days respectively. These periods of exposure and concentration were chosen based on prior food preference studies $(1,2,3$ and $4 \%$ of $\mathrm{NaCl}$ and MSG) which showed nymphs of cockroaches consumed more diet compounded with 4\% MSG, hence a lower concentration was also chosen. The nymphs consumed about $42 \mathrm{mg}$ /day of the MSG diet (Data not shown).

\section{Determination of acetylcholinesterase (AchE), oxidative stress and antioxidant activity markers}

Following the period of exposure, nymphs were anaesthetized on ice, the heads carefully excised, weighed and homogenized in ice-cold $0.1 \mathrm{M}$ phosphate buffer,
pH 7.4, using $100 \mathrm{mg}$ head: $1 \mathrm{~mL}$ buffer and centrifuged at $2500 \times g$ for $10 \mathrm{~min}$ at $4{ }^{\circ} \mathrm{C}$ to obtain a supernatant that was utilized for biochemical estimations. The protein content was estimated using UV-visible 1650 PC Spectrophotometer (Shimadzu) at $280 \mathrm{~nm}$.

Acetylcholinesterase activity was estimated with the method of Ellman et al. [16]. We used $110 \mu \mathrm{L}$ distilled water, $50 \mu \mathrm{L} 0.1 \mathrm{M}$ potassium phosphate buffer $(\mathrm{pH}$ 7.4), $30 \mu \mathrm{L}$ sample $(0.8 \mathrm{mg} / \mathrm{ml}$ protein $), 20 \mu \mathrm{L} 10 \mathrm{mM}$ DTNB, and $20 \mu \mathrm{L} 8 \mathrm{mM}$ acetylthiocholine. The Spectra Max plate reader was set at $412 \mathrm{~nm}, 24 \mathrm{~min}(30 \mathrm{~s}$ interval) and results were expressed as $\mu$ molthiocholine formed $/ \mathrm{min} / \mathrm{mg}$ protein.

The quantification of $2^{\prime}, 7^{\prime}$-dichlorofluorescein (DCFH) oxidation to assess the intracellular level of RONS, a general index of oxidative stress was done [17]. The mixture consisted of $150 \mu \mathrm{L} 0.1 \mathrm{M}$ potassium phosphate buffer (pH7.4), $40 \mu \mathrm{L}$ distilled water, $5 \mu \mathrm{L}$ $200 \mu \mathrm{M}$ DCFH-DA and $5 \mu \mathrm{L}$ tissue sample $(0.2 \mathrm{mg} / \mathrm{ml}$ protein). The emission of DCF fluorescence resulting from DCFH oxidation was analyzed for $45 \mathrm{~min}(30 \mathrm{~s}$ intervals) at 488 and $525 \mathrm{~nm}$, excitation and emission wavelengths respectively, using a spectra Max plate reader (Molecular Devices, CA, USA). The rate of DCF formation was expressed as arbitrary units.

Thiobarbituric acid reactive substances (TBARS) were measured according to the established method [18]. Heads of cockroaches were homogenized in the ratio $1 \mathrm{mg}$ to $5 \mu \mathrm{L} 0.1 \mathrm{M}$ potassium phosphate buffer (pH 7.4). $200 \mu \mathrm{L}$ of the resultant supernatant and 400 $\mu \mathrm{L}$ of stock reagent (equal ratio of trichloroacetic acid $(10 \%, \mathrm{w} / \mathrm{v})$ and 2 -thiobarbituric acid $(0.75 \%, \mathrm{w} / \mathrm{v})$ in $0.1 \mathrm{M} \mathrm{Hcl}$ ) were incubated $\left(95^{\circ} \mathrm{C}, 60 \mathrm{~min}\right)$, cooled, centrifuged $(8000 \mathrm{x} \mathrm{g}, 10 \mathrm{~min})$ and read at $532 \mathrm{~nm}$. Weight of cockroach head was used to normalize results that were expressed as nmol MDA/g tissue.

Catalase activity measures the rate of disappearance of hydrogen peroxide. The reaction medium consisted of $850 \mu \mathrm{L} 0.05 \mathrm{M}$ potassium phosphate buffer ( $\mathrm{pH} 7.0$ ), $60 \mu \mathrm{L}$ sample $(0.8 \mathrm{mg} / \mathrm{ml}$ protein $)$, and $90 \mu \mathrm{L} 500 \mathrm{mM}$ hydrogen, peroxide according to the method of Aebi [19] with slight modifications. The assay was monitored for $4 \mathrm{~min}(20 \mathrm{~s}$ interval) at $240 \mathrm{~nm}$ using a spectra Max plate reader (Molecular Devices, CA, USA) and the results were expressed as $\mu \mathrm{mol}$ of $\mathrm{H}_{2} \mathrm{O}_{2}$ consumed/ $\mathrm{min} / \mathrm{mg}$ protein.

Glutathione-S-transferase activity was estimated by modifying the method of Habig and Jakoby [20]. The system had $135 \mu \mathrm{L} 0.1 \mathrm{M}$ potassium phosphate buffer (pH 6.5), $50 \mu \mathrm{L}$ of tissue sample $(0.2 \mathrm{mg} / \mathrm{ml}$ protein), $100 \mu \mathrm{L} 3 \mathrm{mM}$ glutathione, and $15 \mu \mathrm{L} 20 \mathrm{mM}$ CDNB. The spectra Max plate reader was set at $340 \mathrm{~nm}, 18 \mathrm{~min}$ 
(30 s interval) and results were expressed as $\mu \mathrm{mol} / \mathrm{min} /$ mg protein.

\section{Statistical analyses}

Data were expressed as mean \pm standard error of mean. One-way analysis of variance (ANOVA) and Tukey's post hoc test were utilized for data analyses and significance was considered at $\mathrm{p}<0.05$.
Results

Acetylcholinesterase (AChE), redox and antioxidant activities of cockroaches exposed to $4 \%$ MSG and $1 \%$ MSG for 30 days

There was no significant difference in AchE (Fig. 1b), redox (Fig. 2b, d) and antioxidant activities (Fig. 3b, d) in cockroaches exposed to 1\% MSG. Cockroaches exposed to diets containing 4\% MSG showed a significant decrease in AChE activity by $40 \%$ (Fig. 1a), significant
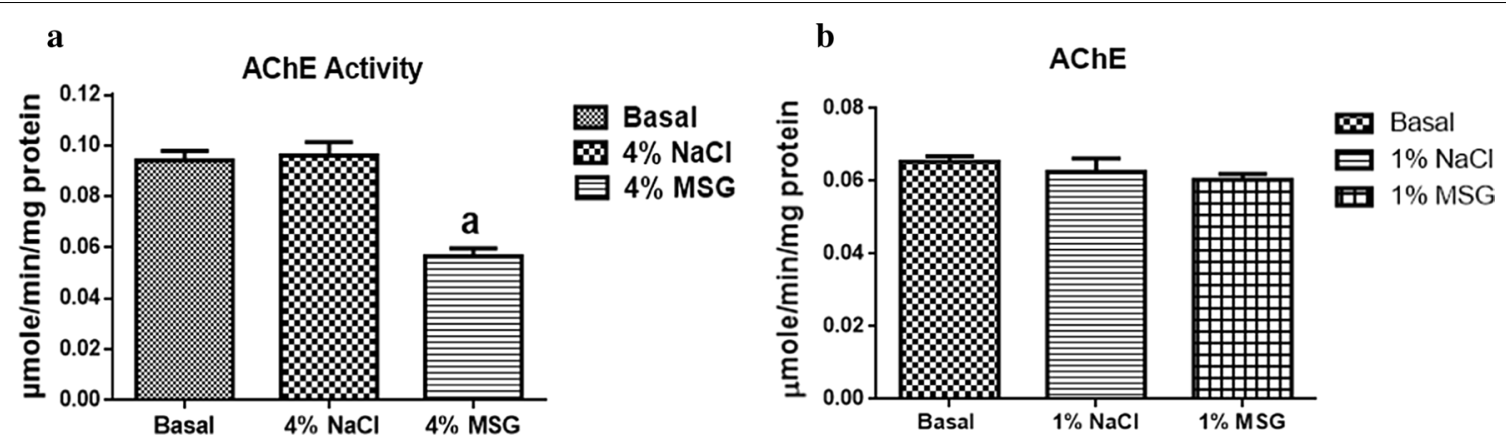

Fig. 1 Acetylcholinesterase (AChE) activities of nymphs exposed to 4\% MSG (a) and 1\% MSG (b). The data are expressed as mean \pm standard error mean (SEM). (a) differs significantly from the basal $(p<0.05)$

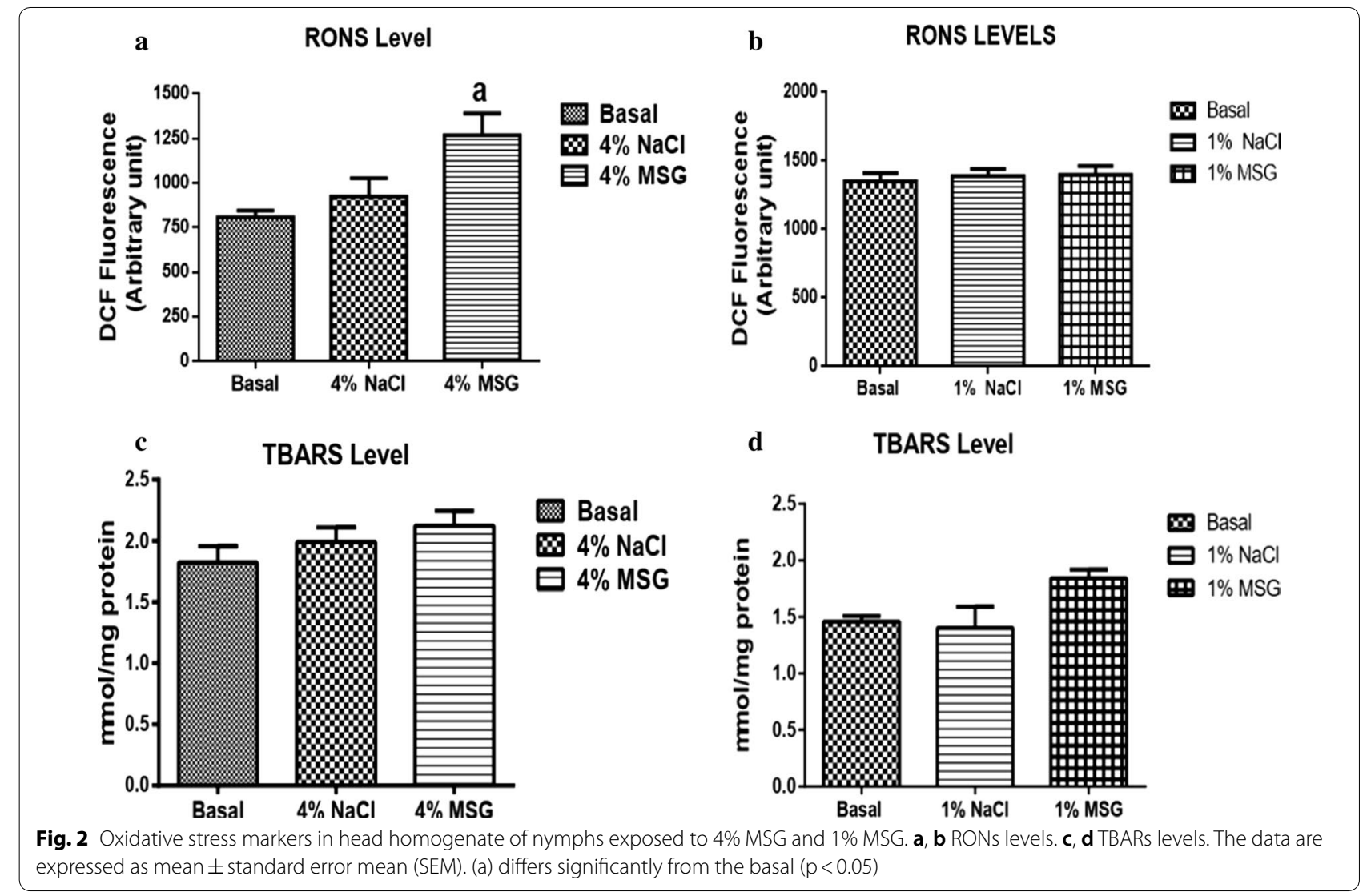



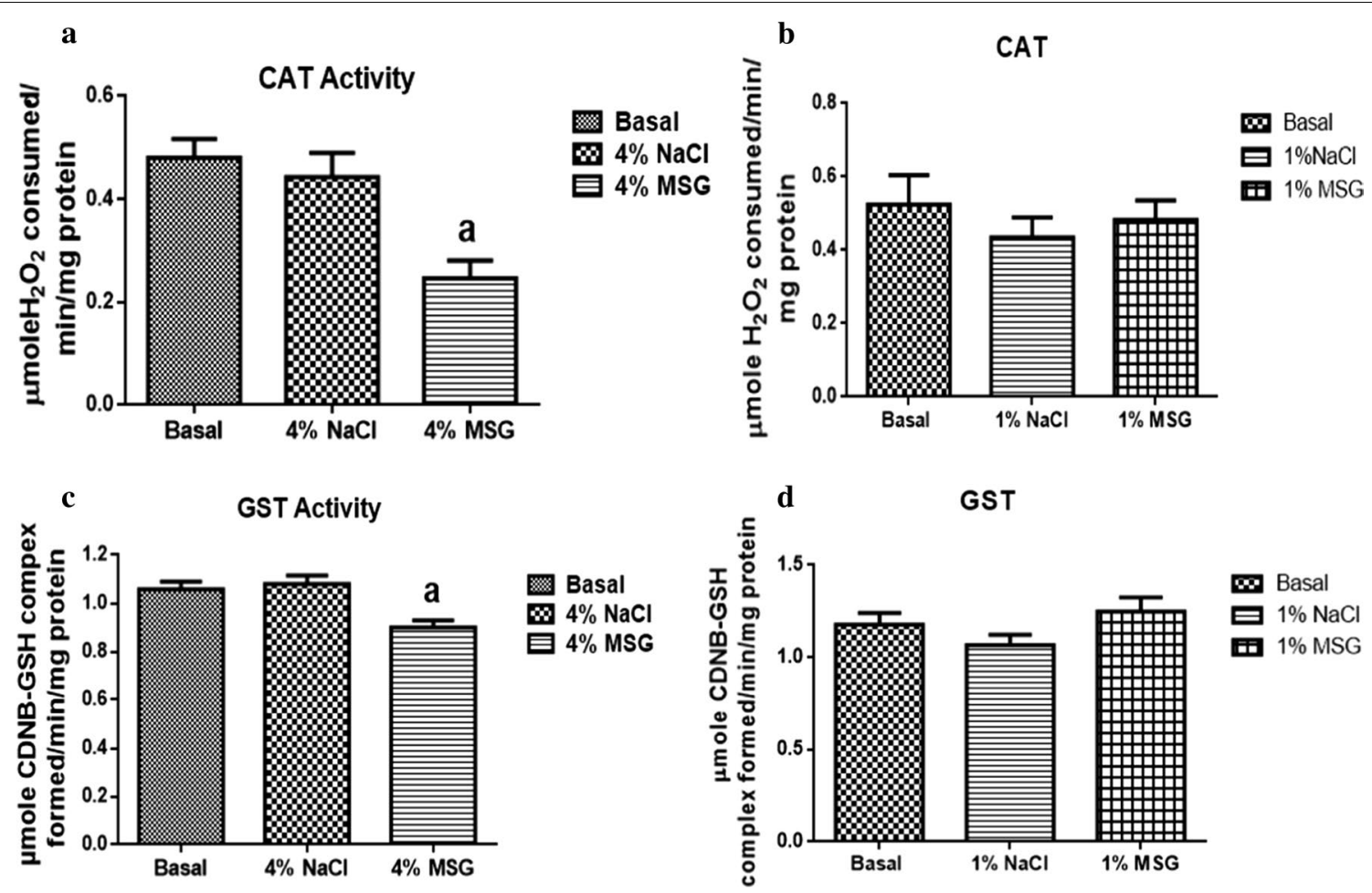

Fig. 3 Antioxidant levels in head homogenate of nymphs exposed to 4\% MSG and 1\% MSG. a, b Catalase activities. c, d Glutathione-S-transferase (GST) activities. The data are expressed as mean \pm standard error mean (SEM). (a) differs significantly from the basal $(p<0.05)$

increase in RONS activity by $42 \%$ (Fig. 2a), no significant difference in TBARS levels (Fig. 2c), significant decrease in CAT activity by $49 \%$ (Fig. $3 a$ ), and significant decrease in GST activity by $15 \%$ (Fig. 3c) when compared to the basal group (control).

\section{Discussion}

There has been widespread use of alternative models in neuroscience to assess the safety and toxicity of chemical substances $[21,22]$. N. cinerea, a valid alternative model organism for basic toxicological studies has been reported to offer new insights for translational neuroscience research [12]. MSG has been established as a neurotoxicant in rodents and has recently been demonstrated to induce an adaptive response to oxidative stress in Drosophila melanogaster [8, 23, 24]. The present study reports some biochemical endpoints in the $N$. cinerea model following exposure to diets containing 4\% MSG and $4 \% \mathrm{NaCl}$ as well as, $1 \%$ MSG and $1 \% \mathrm{NaCl}$ for 30 days.

Acetylcholinesterase (AChE) hydrolyses acetylcholine at synapses into thiocholine and acetic acid, thus playing a role in cholinergic neurotransmission as a biomarker for evaluating the functioning of the nervous system and the diagnosis of neurodegenerative diseases. Our study showed 4\% MSG-treated cockroaches presented decreased AChE activity. Neurotransmission in the insect brain has both cholinergic and glutamatergic components $[25,26]$ and findings by Ortuño-Sahagún et al. [27] depict cholinergic interneurons in the cerebral cortex as major targets for glutamate-the main excitatory neurotransmitter in insects. It is therefore plausible that the administration of a glutamate source would enhance acetylcholine availability probably by suppressing $\mathrm{AChE}$ activity.

Chromosomal damage, as well as increased generation of reactive oxygen and nitrogen species are widely reported in insects exposed to MSG $[8,28,29]$. We equally found significant increase in RONS generation in 4\% MSG treated cockroaches, though TBARS levels were unaffected. The brain is known to be susceptible to free radical damage because of its high concentration of polyunsaturated fatty acids, relatively low antioxidant capacity, high rate of oxygen use, and high concentration of transition metals in some of its' regions [30]. Reports differ on the effect of MSG on Drosophila melanogaster antioxidant response $[8,9]$ we herein show reduced CAT and GST activities in N. Cinerea exposed to $4 \%$ MSG, suggesting that MSG might overwhelm the 
antioxidant and detoxification capabilities of insects. It is clear that at high concentration, MSG may disrupt antioxidant defence systems, nevertheless, nymphs exposed to 1\% MSG showed no significant alterations in all parameters evaluated. We hypothesise that MSG is not toxic at low concentrations in the $N$. cinerea model, hence the safety of small concentrations of MSG for human consumption, even though clinical studies on MSG toxicity are scanty in the literature.

\section{Limitation}

More information to establish the outcome of this study would be acquired if more antioxidant enzyme activities and glutamate levels were assessed in the heads of nymphs of exposed cockroaches. Moreover, this study shows basic information on the likely toxic effect of high concentration of MSG based on the activities of the antioxidant enzymes and primary cholinesterase (AChE) evaluated.

\section{Abbreviations}

MSG: Monosodium glutamate; CAT: Catalase; GST: Glutathione-S-transferase; AChE: Acetylcholinesterase; $\mathrm{NaCl}$ : Sodium chloride; M: Molar; mM: Millimolar; $\mu \mathrm{L}$ : Microliter; g: Relative centrifugal force.

\section{Acknowledgements}

Not Applicable.

\section{Authors' contributions}

BAA designed the study. BAA and OCO conducted the analysis, wrote, read, revised and approved the final manuscript. Both authors read and approved the final manuscript.

\section{Funding}

Blessing A. Afolabi and Olawande C. Olagoke are beneficiaries of the CNPqTWAS 2015 (FR number: 3240286510) and 2017 (FR number: 3240299312) Postgraduate Fellowship respectively. We were paid monthly stipends and bench fees for disposables in the course of experimenting and writing-up for this article.

\section{Availability of data and materials}

The data used and analyzed during the present study are available from BAA on reasonable request.

\section{Ethical approval and consent to participate}

Not applicable.

\section{Consent for Publication}

Not applicable.

\section{Competing of interests}

The authors declare there are no competing interests.

\section{Author details}

${ }^{1}$ Departamento de Bioquímica, Instituto de Ciências Básicas da Saúde, Universidade Federal do Rio Grande do Sul, Rua Ramiro Barcelos 2600-Anexo, 90035-003 Porto Alegre, RS, Brazil. ${ }^{2}$ Departamento de Bioquímica e Biologia Molecular, Centro de Ciências Naturais e Exatas (CCNE), Universidade Federal de Santa Maria, 97105-900 Santa Maria, RS, Brazil. ${ }^{3}$ Department of Biochemistry, Bowen University, Iwo, Osun State, Nigeria.
Received: 7 November 2019 Accepted: 1 April 2020

Published online: 16 April 2020

\section{References}

1. Ikeda K. New seasonings. Chem Senses. 2002;27:847-9.

2. Geha RS, Beiser A, Ren C, Patterson R, Greenberger PA, Grammer LC, Ditto AM, Harris KE, Shaughnessy MA, Yarnold PR, Corren J. A review of alleged reaction to monosodium glutamate and outcome of a multicenter double-blind placebo-controlled study. J Nutr. 2000. https://doi.org/10.1093/ jn/130.4.1058S.

3. He K, Du S, Xun P, Sharma S, Wang H, Zhai F, Popkin B. Consumption of monosodium glutamate in relation to incidence of overweight in Chinese adults. China health and nutrition survey (CHNS). Am J Clin Nutr. 2011;93:1328-36.

4. Shivasharan BD, Nagakannan P, Thippeswamy BS, Veerapur VP. Protective effect of Calendula officinalis $L$. flowers against monosodium glutamate induced oxidative stress and excitotoxic brain damage in rats. Ind J Clin Biochem. 2013:28:292-8.

5. Farombi EO, Onyema OO. Monosodium glutamate: induce oxidative damage and excitotoxicity in the rat. Modulatory role of vitamin C, vitamin E and quercetin. Hum Exp Toxicol. 2006;25:251-9.

6. Onaolapo OJ, Onaolapo AY, Akanmu MA, Gbola O. Evidence of alterations in brain structure and antioxidant status following 'low-dose' monosodium glutamate ingestion. Pathophysiology. 2016;23:147-56.

7. Paul MV, Abhilash M, Varghese MV, Alex M, Nair RH. Protective effects of alpha-tocopherol against oxidative stress related to nephrotoxicity by monosodium glutamate in rats. Toxicol Mech Methods. 2012;22:625-30.

8. Abolaji AO, Olaiya CO, Oluwadahunsi OJ, Farombi EO. Dietary consumption of monosodium L-glutamate induces adaptive response and reduction in the lifespan of Drosophila Melanogaster. Cell Biochem Funct. 2017;35(3):164-70.

9. Kasozi Kl, Namubiru S, Kiconco O, Kinyi HW, Ssempijja F, Ezeonwumelu JOC, Ninsiima HI, Okpanachi AO. Low concentrations of monosodium glutamate (MSG) are safe in male Drosophila melanogaster. BMC Res Notes. 2018;11:670.

10. Afolabi BA, Isaac AA, Diogo OS, João BTR. Dietary co-exposure to methylmercury and monosodium glutamate disrupts cellular and behavioral responses in the lobster cockroach, Nauphoeta Cinerea Model. Environ Toxicol Pharmacol. 2018;64:70-7.

11. Rodrigues NR, Nunes ME, Silva DG, Zemolin AP, Meinerz DF, Cruz LC, Pereira AB, Rocha JB, Posser T, Franco JL. Is the lobster cockroach Nauphoeta cinerea a valuable model for evaluating mercury induced oxidative stress? Chemosphere. 2013;92:1177-82.

12. Zemolin AP, Cruz LC, Paula MT, Pereira BK, Albuquerque MP, Victoria FC, Pereira AB, Posser T, Franco JL. Toxicity induced by Prasiola crispa to Fruit Fly Drosophila melanogaster and Cockroach Nauphoeta cinerea: Evidence for bioinsecticide action. J Toxicol Environ Health A. 2014;77:115-24.

13. Afolabi BA, Olagoke OC, Souza DO, Aschner M, Rocha JB, Segatto AL. Modified expression of antioxidant genes in lobster cockroach, Nauphoeta cinerea exposed to methylmercury and monosodium glutamate. Chemico Biological Interact. 2020;25(318):108969.

14. Stankiewicz M, Da Browski M, De Lima ME. Nervous system of Periplaneta americana cockroach as a model in toxinological studies: a short historical and actual view. J Toxicol. 2012. https://doi.org/10.1155/2012/143740.

15. Harris WE, Moore PJ. Female mate preference and sexual conflict: females prefer males that have had fewer consorts. Am Nat. 2005;165:S64-71.

16. Ellman GL. Tissue sulfhydryl groups. Arch Biochem Biophys. 1959;82:70-7.

17. Piccoli BC, Alvim JC, da Silva FD, Nogara PA, Olagoke OC, Aschner M, Oliveira CS, Rocha JBT. High level of methylmercury exposure causes persisted toxicity in Nauphoeta cinerea. Environ Sci Pollut Res. 2020;27(5):4799-813.

18. Puntel RL, Roos DH, Grotto D, Garcia SC, Nogueira CW, Rocha JBT. Antioxidant properties of Krebs cycle intermediates against malonate pro-oxidant activity in vitro: a comparative study using the colorimetric method and HPLC analysis to determine malondialdehyde in rat brain homogenates. Life Sci. 2007:81(1):51-62.

19. Aebi H. Catalase in vitro. Methods Enzymol. 1984;105:121-6.

20. Habig WH, Jakoby WB. Assays for differentiation of glutathione S-transferases. Methods Enzymol. 1981;77:398-405. 
21. Schechtman LM. Implementation of the 3 Rs (refinement, reduction, and replacement) validation and regulatory acceptance considerations for alternative toxicological test methods. ILAR J. 2002;43:S85-94.

22. Peterson RT, Nass R, Boyd WA. Use of non-mammalian alternative models for neurotoxicological study. Neurotoxicology. 2008;29:546-55.

23. Olney JW. Brain lesions, obesity, and other disturbances in mice treated with monosodium glutamate. Science. 1969:164:719-21.

24. Kubo T, Kohira R, Okano T, Ishikawa K. Neonatal glutamate can destroy the hippocampal CA1 structure and impair discrimination learning in rats. Brain Res. 1993;616:311-4.

25. Kratsios P, Stolfi A, Levine M, Hobert O. Coordinated regulation of cholinergic motor neuron traits through a conserved terminal selector gene. Nat Neurosci. 2012;15(2):205-14.

26. Stein W, Smarandache CR, Nickmann M, Hedrich UBS. Functional consequences of activity-dependent synaptic enhancement at a crustacean neuromuscular junction. J Exp Biol. 2006;209(7):1285-300.
27. Ortuño-Sahagún D, Beas-Zárate C, Adame-Gonzalez G, Feria-Velasco A Effect of L-glutamate on cholinergic neurotransmission in various brain regions and during the development of rats, when administered perinatally. Neurochem Int. 1997;31:683-92.

28. Ataseven N, Yüzbaşioğlu D, Keskin AÇ, Ünal F. Genotoxicity of monosodium glutamate. Food Chem Toxicol. 2016;91:8-18.

29. El-Keredy A. Genetic and behavioural influences of quinine and monosodium glutamate on Drosophila melanogaster. Egypt J Genet Cytolo. 2014:43(2):377-91.

30. Evans PH. Free radicals in brain metabolism and pathology. Br Med Bull. 1993;49:577-87.

\section{Publisher's Note}

Springer Nature remains neutral with regard to jurisdictional claims in published maps and institutional affiliations.
Ready to submit your research? Choose BMC and benefit from:

- fast, convenient online submission

- thorough peer review by experienced researchers in your field

- rapid publication on acceptance

- support for research data, including large and complex data types

- gold Open Access which fosters wider collaboration and increased citations

- maximum visibility for your research: over $100 \mathrm{M}$ website views per year

At BMC, research is always in progress.

Learn more biomedcentral.com/submissions 